\title{
From the Colombian Coca Fields: Peasant Women Amid the War on Drugs
}

\author{
Isabel Pereira and Lucía Ramírez
}

\section{Introduction}

In Colombia, the 'war on drugs' has served as a breeding ground for armed conflict, poverty, and stigmatisation. Coca crops are at the centre of the debate over state and peacebuilding. According to the United Nations Office on Drugs and Crime (UNODC) in 2018, the country had a total of 169,018 hectares of coca, of which 15\% were in Putumayo (Colombian Drug Observatory, 2019). There is enormous pressure to reduce this figure in order to secure peace in rural areas and to increase the state's presence in historically neglected regions.

Putumayo has been a key player in Colombia's collective memory on illicit crops. Coca, which has existed in this department for approximately 40 years, radically changed the lives of its inhabitants offering many cultivators a way out of poverty. Putumayo's history is marked by, on the one hand, a national government that has made its presence in the area through the deployment of military force and, on the other hand, the efforts of local communities to provide themselves with the basic services needed to live with dignity (Torres, 2011).

While the context of state-building and social mobilisation spurred by the coca economy in Putumayo has been widely documented, the experience of cocaleras has not. Ignoring women's perspectives in these processes means overlooking key experiences that help us understand how social inequality operates and is exacerbated through policies such as the militarisation of regions stigmatised as coca havens, and how women mobilise and resist violence, with community and solidarity efforts.

Women participate in the coca economy in a variety of ways, including by caring for and feeding workers, harvesting, processing, and selling the plant and its derivatives. The cocaleras are rural women whose life trajectory is marked by

\footnotetext{
The Impact of Global Drug Policy on Women: Shifting the Needle, 169-178 Copyright $(\mathcal{2} 2021$ by Isabel Pereira and Lucía Ramírez These works are published under the Creative Commons Attribution (CC BY 4.0) licence. Anyone may reproduce, distribute, translate and create derivative works of these works (for both commercial and non-commercial purposes), subject to full attribution to the original publication and authors. The full terms of this licence may be seen at http://creativecommons.org/licences/by/4.0/legalcode doi:10.1108/978-1-83982-882-920200023
} 
responsibility for most household tasks, while also actively participating in productive work in the fields. These women, raised to be caregivers, also quickly become breadwinners together with the men, who perform productive work but are not usually expected to do household chores. We document the experiences of cocaleras and their relationship with coca and drug policies; hearing their voices is the first step in grasping their complex realities.

We collected this information during the Regional Conference of cocaleras in Puerto Asís in 2017 - organised by Dejusticia and the agricultural trade union Fensuagro - which brought together 43 women. We used participatory mapping techniques to document women's daily routines, relationships with coca, family experiences, definitions of the state, and relationships with armed actors. In addition, we conducted in-depth semi-structured interviews with seven participants, whose names have been changed to protect their privacy. These interviews sought to trace the women's life trajectories and to reveal the complexities in being a 'cocalera'.

We adopted three angles in our analysis: (i) an intersectional approach; (ii) a subjective approach to the state; and (iii) an approach based on women's voices. From the intersectional standpoint, we recognise that lives of cocaleras involve multiple forms of social inequality; they are peasant women, which in Colombia implies four types of oppression on account of (i) being women, (ii) being cultivators, (iii) being poor, and (iv) being victims of the armed conflict (UNDP, 2011). Moreover, cocaleras are involved in an illicit and stigmatised economy, which adds another layer of oppression, in which their lived experience of the state, plays a central role.

The second two angles are expressed by positioning their voices and experiences of the state at the centre. If neither public institutions nor academia has paid much attention to cocaleras, it is ethically and politically imperative that this gap is filled from a subjective perspective. Making their stories known was a call for justice, amidst the harsh reality of impunity in which they find themselves.

\section{Setting the Scene: The Lives of Cocaleras in Putumayo}

The department of Putumayo has been historically characterised by high poverty rates, unbridled natural resource extraction, the presence of armed actors vying for territorial control, the systematic violation of human rights, and a high prevalence of illicit crops. After the state's failed colonisation effort that took place in the mid-1960s, and against the backdrop of declining oil activities, the coca economy emerged in the late 1970s, a period which led to a demographic explosion in the region, of people searching for possibilities and opportunities, and land.

Putumayo has been seen as a 'vacant, depraved, and barbaric' area, neglected by national policies (UNODC \& APC, 2007, p. 229). Today, the state of neglect continues due to the persistence of factors that have negatively affected the region, such as legal and illegal economies, the presence of armed actors, the lack of social and economic development among the rural population, and territorial disputes related to oil exploration and exploitation (Centro Nacional de Memoria Histórica (CNMH), 2015). 
Putumayo's score on the multidimensional poverty index is $76.3 \%$, compared to the national score of $49 \%$ (Departamento Nacional de Planeación (DNP), 2015 ) and $26.5 \%$ of the department's urban population and $46.2 \%$ of its rural population have unsatisfied basic needs (UNDP, 2016). Forced displacement, sexual violence, assassinations, and forced disappearances are among the various forms of victimisation that are part of the daily lives of communities in Putumayo.

Regarding education, $12.6 \%$ of the rural population above the age of 15 is illiterate; in addition, $20.3 \%$ of the population aged 5 to 16 and $73.7 \%$ of the population aged 17 to 24 are not enrolled in or lack access to schooling (Departamento Administrativo Nacional de Estadística (DANE), 2015, pp. 23-26). There is not even one higher education institution in the region.

In terms of the right to work, studies reveal two trends in rural areas that impede the fulfilment of this right: the first is the persistence of informal labour, low wages, and the absence of employment opportunities; the second, which has to do especially with rural women, is the sexual division of labour that places a larger burden of unpaid care work on women. The participation of women in the labour force is not fully accounted for, moreover, their full load of work is obscured (Misión para la Transformación del Campo, 2015).

The National Quality of Life Survey estimates that $95.3 \%$ of the rural population is enrolled in the health care system - of whom $81.8 \%$ are in the subsidised regime (DANE 2017, pp. 11, 13) - but despite this, a number of structural barriers in the health system prevent rural residents from effectively accessing their right to health. Among these obstacles are a lack of available health programmes and services, insufficient facilities, geographical barriers, costs (co-payments, medicines, and transportation costs), poor coordination between health centres and hospitals, and a lack of information (MSF Colombia, 2011).

While poverty and precariousness prevail, the means to purchase a parcel of land and build a home are scarce. This situation is exacerbated for women, who face barriers to accessing credit as a result of their low participation rate in paid employment, their lack of secure land tenure, and their greater dedication to household and domestic work.

This department is the second with the greatest proportion of land informality, which stands at 33\% (Instituto Geográfico Agustín Codazzi (IGAC), Universidad del Rosario, \& Universidad de los Andes, 2012, pp. 437, 443). This picture is made even bleaker by the way that illicit drug trafficking and armed conflict have led to forced abandonment and land dispossession in Putumayo (Centro Nacional de Memoria Histórica (CNMH), 2015, p. 281). During our fieldwork, it became clear that women who have access to land see it as the source of families' food security. They use part of their land to plant subsistence crops for their families while the men focus their efforts on commercial crops, such as coca.

Given the state's failure to guarantee the population's economic, social, and cultural rights, communities themselves, particularly under women's leadership, have assumed the task of securing the basic goods and conditions needed to ensure their well-being and security. Rosaura's testimony on the construction of tertiary roads offers one example: 
My colleague Violeta and I are on the road committee. The road was very bad, full of muddy holes. We got really involved, we pleaded with the mayor, with the council members but nothing happened. So, we collected funds, so we could apply materials to the road surface [...] And now people say that after being so ugly, the road is looking good again. So now we're focusing on trying to get a bridge.

Cocaleras significant mobilisation capacity is what has built Putumayo in a context of adversity. In addition to participating in community action boards, they sit on committees aimed at infrastructure improvements. Without women's contributions and leadership, their communities would undoubtedly be worse off than they are today. Women have assumed important mobilising and organising roles that have helped ensure access to basic goods that the state has failed to provide. Their work expands beyond the family and touches their entire communities, for roads, health, and education are all goods that improve the well-being of those who inhabit the same region.

\section{Women Who Grow Coca: Gains, Losses and Hopes}

The coca economy has allowed women to overcome shortcomings in the fulfilment of their rights and access to basic goods but has also placed them at the centre of violence and vulnerability as a result of the militarisation of their lands, the stigmatisation of their work, and the presence of armed actors linked to the drug trade and to internal armed conflict. This section is divided into two parts: first, we explore the positive and negative impacts that coca has had on women's lives, and second, we document the impacts of the state's response which include militarisation and forced eradication.

\section{Reasons for Cultivating Coca: 'We Grew Coca with the Best of Intentions - To Be Able to Give Our Children an Education.'}

Cultivating coca has allowed many peasant families to survive in contexts of extreme economic and social hardship. According to the women we interviewed, their involvement in coca was a response to poverty. In the words of María Fernanda, 'We're not growing coca because we like it, but simply because it has allowed us to survive in the countryside'. There is a market for coca, and unlike other agricultural products, which enjoy neither the conditions nor a stable market to ensure regular earnings, coca's transport and sale does not require much infrastructure.

Coca has a longstanding presence in women's memories. Their earliest memories are nostalgic ones, as Sandra recalls:

My first memory of coca is when my dad, seeing our desperate economic situation, decided to sell a cow and buy coca seeds to plant. After he sold his first harvest and came home [Sandra smiles]... he left home with a little bag and came home with a huge sack - he brought us all kinds of things! And the next week, he 
said, 'Okay, two of you are coming with me again to Puerto Asís to help with the shopping'. He bought us shoes, boots, clothes, and he kept on doing it [over time]. So, my first memory of coca is one of happiness. It filled a big need.

The involvement in coca cultivation brought, as Sandra says, happiness for women. This included issues that are not minor, such as greater economic independence and the ability to access fundamental rights including housing, education, and health. Coca also allowed some women to earn enough to purchase land, improve their farms, and make investments in their properties. In this regard, as Gloria Oliva recounted,

We began to plant coca, and our first harvest yielded about 70 arrobas [793 kilos], and that is how we got started. We bought a little piece of land with the money we made, because the land where we had been planting wasn't ours, it was rented.

Regarding health care, the coca economy has allowed women to pay out of pocket for private doctors, given the difficulties and shortcomings in accessing care via the public health system. Viviana explained how she was able to pay for checkups during her third pregnancy thanks to the money she earned through coca:

My health coverage is subsidized, but since I needed certain exams due to my high-risk pregnancy, which my insurance didn't cover, I had to pay out of pocket for appointments. And because we had gone through a [difficult] experience with our second child, we didn't want anything to happen to our third baby.

These positive outcomes were met with negative ones when the presence of armed actors affected peace in the region, and the state responses based on predominantly repressive drug policies brought disastrous effects for communities and particularly women. The state rolled out an intensive military strategy in Putumayo aimed at, on the one hand, dismantling leftist guerrillas and, on the other hand, eradicating illicit crops, as required by national and international drug control policies. Within this context, the state neglected the construction of an efficient public administration that fostered the necessary conditions for structural equality within the population (García \& Revelo, 2010).

This had severe negative impacts on the lives of cocalero families in Putumayo, as seen in various ways: (i) it involved interference by the armed forces in the daily lives of communities; (ii) it was carried out in coordination with paramilitary groups, who used the threat of violence to impose restrictive gender roles; and (iii) it promoted indiscriminate aerial spraying that damaged licit and illicit crops causing negative repercussions for livelihoods.

Living in an area dominated by illicit crops has led to a state-community relationship marked by an imbalance of power, which has meant the excessive use of force and the stigmatisation of local populations on account of their supposed links with armed actors via the coca trade. The armed forces, paramilitary groups, 
and guerrillas fought for control of various regions, which, as highlighted by the women we interviewed, left civilians squarely within military operations and in the crossfire of various armed actors (CNMH, 2013, p. 156).

Alongside this militarisation came the stigmatisation of women and their families, who were accused by the armed forces of being guerrillas and drug traffickers. Militarisation and the war on drugs pushed cultivators from their status as citizens to a new status as enemies of the state - enemies who, accordingly, lost access to the rights and well-being that the state was obligated to ensure, instead becoming targets of retaliation and criminal prosecution. María Fernanda described this stigmatisation:

When the soldiers would come to people's homes, they weren't respectful $[\ldots]$ they start looking at your hands, because when you grow coca you have fingers like me... crooked from scraping coca leaves, and calloused. So, when they tell you to show them your hands, they know.

As a result, the department's inhabitants, among them cocaleras, have suffered multiple forms of victimisation. According to figures compiled by the Victims' Registry, as of 1 July 2017, a total of 269,137 people had been victimised in Putumayo. Of these, $50 \%$ were women, $49 \%$ were men, and $1 \%$ were members of the LGBTI community or individuals who did not report their sex (UARIV, 2016). Many cocaleras are victims of armed conflict; however, the state - with the war on drugs as its focus seems to place more emphasis on their status as coca growers and not as victims.

The territorial disputes extended to women's bodies, which become a place for armed actors to wage war; women are in the crosshairs of the conflict. Women's testimonies show how sexual violence was used as a strategy to terrorise, subdue, and humiliate women, stigmatised as criminals, cocaleras, and guerrilla fighters. Despite the lack of information about the use of sexual violence as a weapon of war in the region, studies from the National Center for Historical Memory show that in addition to being prevalent during massacres, sexual violence was an inherent risk in women's daily coexistence with paramilitary actors.

All of this demonstrates that the experience of cocaleras is defined, in part, by the fact that they are often direct victims of the armed conflict in numerous ways. Women's relationship with coca tells us about their struggle with poverty, their attempt to secure better living conditions for themselves and their families, and their search for economic alternatives in the countryside. But it also shows us how coca put them in contact with a historically absent state through the militarisation of their lands. This relationship with the state shaped by the convergence of anti-drug and counterinsurgent efforts, as the war on drugs and the state's efforts to rid the region of guerrillas placed women in the crossfire, and it stripped them of their status as citizens.

\section{The Impact of Forced Eradication: 'They Came to Eradicate Drugs But Instead Destroyed Our Land'}

Despite numerous calls for integrated rural development as the solution to the coca problem in the region, the Colombian state's main response was forced 


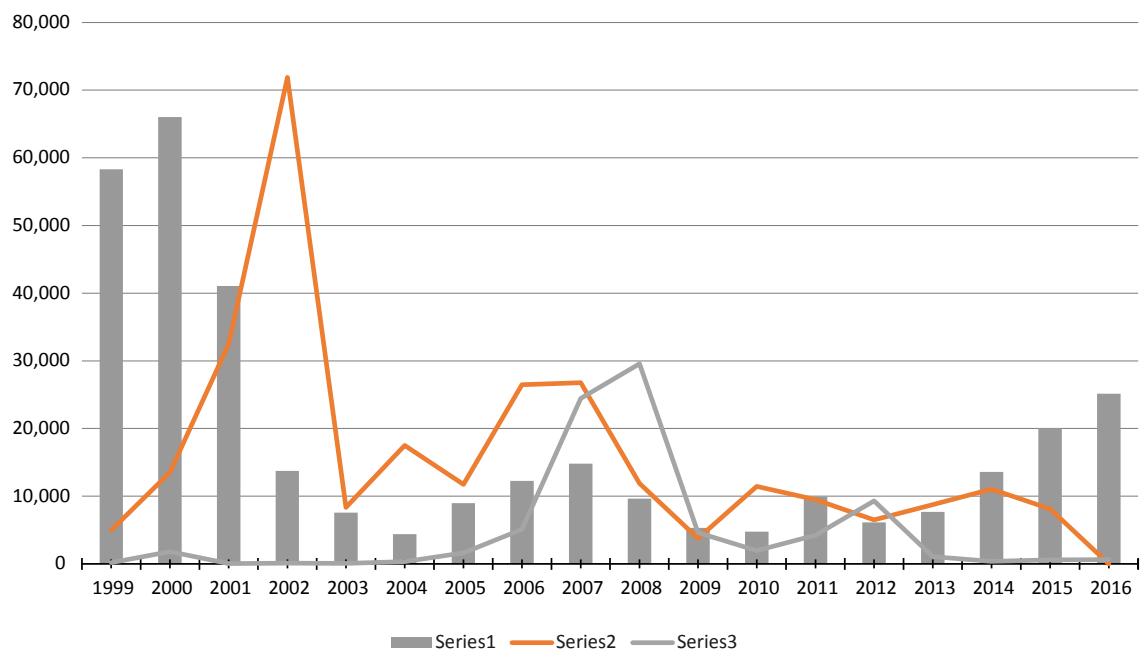

Fig. 1. Coca Crops, Aerial Fumigation, and Manual Eradication in Putumayo (1999-2016). Source: Prepared by the authors using SIMCI data.

eradication of crops in the context of Plan Colombia. A plan under which the Colombian and US governments promised to invest US\$10.9 billion, over a 15-year period to finance the war on drugs and initiatives to eliminate guerrilla violence in the country. Between 2002 and 2015, the state forcibly eradicated 2.2 million hectares of coca crops (DNP, 2016). Eradication consisted mainly of aerial fumigation and, to a lesser extent, manual uprooting. By deploying these mechanisms, the state actively inflicted further victimisation including displacement, disease and food insecurity, on an already victimised community.

The women we interviewed vividly recalled the commencement of fumigations in 2000, given the economic crisis and food insecurity that it sparked for them and their families. Between 2000 and 2002, 117,906 hectares of coca were sprayed in Putumayo with agrotoxic glyphosate. If we consider the fact that nearly 280,000 hectares were fumigated in the department between 2000 and 2015, this amount in just three years represents almost half of the historical fumigation effort in Putumayo territory.

As recorded in a human rights bulletin, in 2002, aerial spraying caused the displacement of 10,813 people in Putumayo. In this state, one of the most common negative health impacts was the harm wreaked by the use of glyphosate, a chemical that not only damaged subsistence crops but also animals and people. María Fernanda explained:

I was seventeen when they began fumigating... When they sprayed, they didn't spray [only] what they were supposed to... because the poison was very strong and damaged our subsistence crops, like plantain, corn, our animals, our pastures where we had cows. And that was just the tip of the iceberg, everything died... The poison also 
infiltrated our water, even us, because we were often in those areas, I mean in the crops when they were fumigating. Some people from our village got skin infections because of the spraying, and there was also a case where a baby was born deformed because of the chemicals.

In terms of the impacts of aerial spraying, the women were emphatic that it ruined not only their coca crops but also their subsistence crops and other ventures that had been supporting their families. As Gloria Oliva noted:

[In 2000], they sprayed our crops. It was awful. They sprayed the pasture, our cassava, plantain, corn, rice. It was something we didn't expect - to be left with bunches of plantains that are damaged... We were left without food. My husband had to go find work somewhere else in order to buy us food.

\section{Violeta recounted:}

The spraying began around 2002. We were growing coca, but just when things are getting off the ground, the downpour [of herbicides] comes and kills it all, then the army comes and rips it out. The fumigators come and destroy it all. And for the community, the last straw was when they sprayed plantain fields, pastures, everything. When they wiped out our subsistence crops, that's where everything died. Everything died, because people had to leave since there was nothing left to harvest.

To make matters worse, the negative health impacts of aerial spraying had to be resolved by the communities themselves. The lack of proximate health services meant that residents could not easily access care. While the aeroplanes fumigated, and while the police and army uprooted inhabitants' coca plants, solutions for rural poverty were nowhere to be found in Putumayo. Once again, this highlight how anti-drug strategies deepened poverty and exacerbated the fragility of cultivators' livelihoods in Putumayo.

This harmful mechanism was suspended in 2015 after the IARC-WHO classification of glyphosate as potentially carcinogenic to humans was published. Subsequently, in a 2017 ruling, Colombia's Constitutional Court ordered the government not to resume the aerial spraying programme with glyphosate, activating the precautionary principle for this case and conditioning reactivation on a set of standards that could better protect fundamental rights of the populations cultivating the coca plant. As of 2020, Colombia's current government is attempting to reactivate the programme, which has faced significant opposition, including from rural labourers.

In the meantime, the state's response to coca crops is met with the challenge of transiting from a repressive response to a constructive response. This is the core of Chapter 4 of the Peace Agreement, signed in 2016 between the national government and the Revolutionary Armed Forces of Colombia (FARC) that 
has five chapters, including one about the 'Solution to the Illicit Drug Problem'. In this chapter, the Colombian State recognises that the persistence of coca in rural Colombia is explained by poverty among other factors, and will then promote voluntary and gradual substitution. To date, 130,000 families have adhered to the programme, although only $76 \%$ (99,000 families) have been officially enrolled. The commitment from the side of cocalero families is evident: according to UNODC, compliance involuntary eradication is at $94 \%$. On the other hand, the state has not fulfilled its side of the bargain: less than $40 \%$ of enrolled families have technical assistance, and many have completed the full cycle of eradication without receiving the subsidies that were promised. Moreover, security conditions in some cocalero regions are fragile, and threats and killings of social leaders that defend the substitution programme are on the rise (Fundación Ideas para la Paz (FIP), 2019). Betting on peace and a licit livelihood is costing entire communities life itself.

The lessons that these women learned from the difficult years of eradication efforts are motivating them to participate in the implementation of the Peace Agreement, but with a deep distrust of the state's resolve to comply with its promises, including the guarantees of security. This implementation, as dictated by the Agreement, needs to be based on community participation and a differentiated approach, by which the gender focus would respect the gains that women have made in the coca economy. However, this has not been the case, and in the rolling out of the Peace Agreement little has been done to effectively promote women's participation. Neither has the Agreement taken into account their concerns or needs. By 2017, when all collective substitution agreements were signed between communities and the government, a mere $26 \%$ of the signatories were women.

Thus, coca remains present in their lives, and these women observe cautiously as new efforts aimed at eradicating and substituting illicit crops come to the fore. In the words of a participant from the regional conference, it is critical that 'this not become another Plan Colombia'.

\section{Conclusion: The Promise of Peace in Rural Colombia}

Today, my dream is to build a complete farm, have a little bit of everything on my land, and hopefully this war will come to an end. And there will be no more conflict. And I can grow old and look at my children with happiness, without worry. And my children will never have to hold a weapon. - Sandra

The relationship of women with coca crops in Putumayo is ambivalent: on the one hand, it has allowed them to find ways to face poverty, seek better living conditions for themselves and their families, and find alternatives for their communities' development. However, cultivating coca has brought them into contact with a historically absent state - a state that has privileged the use of force over the implementation of development projects that address the structural causes of Putumayo's communities being involved in the illegal economy.

The policies of the war on drugs, which have been implemented in this region through militarisation, forced eradication of crops, and excessive use of prison 
and counter-insurgency, have caused serious human rights violations. These have disproportionately affected women. Decisions concerning drug policy fall increasingly outside the hands of the national government and instead depend on transnational-level decision making, where the voices of the weakest links in the drug chain, such as cocaleras, are invisible, and where these actors are rarely able to conduct advocacy.

Cocaleras have had to endure a lack of recognition as rural citizens and as women due to a patriarchal society that reinforces gender-based stereotypes and violence. This problem is not unique to cocaleras, it affects other rural women as well. Nonetheless, in the cocaleras case, their stigmatisation as guerrilla supporters and drug traffickers is an additional element that further reinforces deficits and vulnerability. This stigmatisation, although shared by men in their communities, places cocaleras in an even more precarious situation compared to other women in the rural world.

Due to the absence of civil institutions, communities have developed strong organisational processes in which women have played a fundamental role. The economic independence they have achieved thanks to their work in coca cultivation has allowed them to claim their space in community organisations and ultimately to strengthen their citizenship and become agents of change in their communities. The cocaleras are strong, resilient women with a deep knowledge of their communities.

The stories and experiences of cocaleras from Putumayo show the serious impacts of the war on drugs on their lives. Their reflections and expectations reveal the harms caused by drug policies and it is an ethical imperative to be sure these voices are heard. 